\title{
Uptake of seed-applied copper by maize and the effects on seed vigor
}

\author{
Marcos Altomani Neves Dias ( ${ }^{*}$; Silvio Moure Cicero; Ana Dionísia Luz Coelho Novembre \\ Universidade de São Paulo, Escola Superior de Agricultura “Luiz de Queiroz” (ESALQ), \\ Departamento de Produção Vegetal, Caixa Postal 9, 13418-900 Piracicaba (SP), Brasil. \\ ${ }^{*}$ ) Corresponding author: marcosaltomani@gmail.com
}

Received: Feb. 2, 2015; Accepted: Mar. 16, 2015

\begin{abstract}
Seed treatment is a low-cost and efficacious method to deliver a diversity of compounds to field crops. This study evaluated the uptake of seed-applied Cu by maize and the effect on seed vigor. The treatments were composed of a control (untreated seeds) and five dosages of Cu: 0.11, 0.22, 0.44, 0.88 and $1.76 \mathrm{mg} \mathrm{Cu} \mathrm{seed}^{-1}$, applied as cuprous oxide and copper oxychloride formulations. Seedling emergence and the speed of seedling emergence were determined in three periods: 1,60 and 120 days after Cu application. Evaluations of root and shoot dry mass, Cu tissue concentration and efficiencies of Cu uptake and incorporation were conducted with two-leaf stage maize plants. Seed-applied Cu reduces the speed of maize seedling emergence, while the final emergence percentage is not affected. Shoot dry mass tends to increase with the application of Cu, while there is no interference on root dry mass within the dosages tested. Cu tissue concentration of both roots and shoots increases as higher dosages of Cu are applied to seeds, with higher accumulation in roots. Cuprous oxide promotes higher uptake of Cu by maize roots compared to copper oxychloride.
\end{abstract}

Key words: Zea mays L., seed treatment, seed coating; seed dressing, micronutrients.

\section{INTRODUCTION}

Copper is an essential element for plants, mainly for its participation in photosynthesis, respiration, carbon and nitrogen metabolisms, and protection against oxidative stress (Yruela, 2009). More than 50\% of Cu atoms in plants are present in chloroplasts, as a component of plastocyanin. Thus, in case of $\mathrm{Cu}$ deficiency, photosynthesis is severely affected (Epstein \& Bloom, 2004).

The availability of $\mathrm{Cu}$ to plants is mainly influenced by soil texture, $\mathrm{pH}$, organic matter content and the amount of other nutrients (Malavolta, 2006). The lack of $\mathrm{Cu}$ in soils naturally occurs in many regions worldwide, such as in Brazilian "Cerrado" and other Tropical areas. Moreover, cultivation practices such as superficial liming may contribute to reduce the availability of $\mathrm{Cu}$ to field crops, by excessively elevating the soil $\mathrm{pH}$ at the surface level; this leads to a deficiency of cationic micronutrients, such as $\mathrm{Cu}$, by early developing seedlings (Fageria \& Stone, 2004).

Seed treatment may consist in a feasible option to deliver micronutrients to field crops (Farooq et al., 2012). Considering operational and agronomic aspects, seed treatment contains important characteristics to provide micronutrients to plants, such as relatively low-cost, easy operation, uniform distribution of compounds among plants and availability since the earlier stages of plants growth (Scott, 1998; Taylor et al., 1998).

The initial stages of growth is a crucial phase for the uptake of micronutrients by plants, as higher concentrations of these elements are found in young plant tissues (Cakmak, 2000). A proper supply of micronutrients during this phase may result on a better crop establishment in the field and a faster initial development of plants, which are crucial aspects for obtaining higher grain yields in maize (Dias et al., 2010; Mondo et al., 2013).

Studies involving seed treatment with $\mathrm{Cu}$, in general, presented negative results in terms of seedling emergence and growth. Nazir et al. (2000) and Luchese et al. (2004), studying wheat and maize, respectively, concluded that seed treatment with copper sulphate caused a reduction on seedling emergence. Malhi (2009) and Malhi \& Leach (2012) tested Cu-EDTA formulations applied via maize seeds and also reported toxicity to plants. These negative results might be directly associated to the $\mathrm{Cu}$-containing formulation. According to Scott and Blair (1988), water-soluble formulations (such as copper sulphate and Cu-EDTA) are more readily absorbed by plants and, consequently, are more prone to harm the seeds. 
This study evaluated the feasibility of using two non-water-soluble formulations containing $\mathrm{Cu}$ as maize seed treatment, considering nutritional and seed quality aspects.

\section{MATERIAL AND METHODS}

A maize seed-lot containing non-treated seeds (hybrid 2B688Hx) was used in the study. The lot was submitted to an initial characterization following the procedures described on the Rules for Seed Analysis (Brasil, 2009), providing the following results: $10.3 \%$ of seed moisture content; $330.2 \mathrm{~g}$ of a thousand seeds weight; $92 \% \pm 0.40$ of germination; $86 \% \pm 2.44$ and $80 \% \pm 4.54$ of seed vigor, assessed by the accelerated aging and cold test, respectively.

The seeds were coated with two liquid formulations containing $\mathrm{Cu}$, cuprous oxide (density: $1.49 \mathrm{~g} \mathrm{~cm}^{3}$; $\left.501.3 \mathrm{~g} \mathrm{Cu} \mathrm{dm}^{-3}\right)$ and copper oxychloride $\left(1.72 \mathrm{~g} \mathrm{~cm}^{3}\right.$; $\left.589.0 \mathrm{~g} \mathrm{Cu} \mathrm{dm}^{-3}\right)$. The formulations were applied with a laboratory scale conventional pan coater, equipped with a Leroy-Somer rotating motor (model LS71 $0.75 \mathrm{Kw}$ ). This equipment allowed an uniform coverage of maize pericarp.

The dosages of $\mathrm{Cu}$ corresponded to: $0.11,0.22,0.44$, 0.88 and $1.76 \mathrm{mg} \mathrm{Cu} \mathrm{seed}^{-1}$, for both formulations. After coated, seeds were placed in paper bags and stored under controlled conditions $\left(20^{\circ} \mathrm{C}, 45 \%\right.$ R.H.) along the experiment.

Seed vigor was assessed through the seedling emergence (SE) and speed of seedling emergence tests (SSE), installed at three periods after $\mathrm{Cu}$ application: 1, 60 and 120 days. Both tests were conducted in the same experimental unit, composed of four replicates of 50 seeds per treatment, sowed in polyethylene trays $(0.47 \times 0.30 \times 0.11 \mathrm{~m})$ filled with $8 \mathrm{dm}^{3}$ of sand moistened at $60 \%$ of water holding capacity. The trays were maintained in a greenhouse and irrigated as needed. The speed of seedling emergence (index) was calculated according to Maguire (1962), based on a daily counting of emerged seedlings.

Root and shoot dry mass and $\mathrm{Cu}$ tissue concentration were evaluated with four replicates of 10 plants, cultivated in sand, in the same conditions described previously; in this test, only the dosages $0,0.11,0.44$ and $1.76 \mathrm{mg}$ $\mathrm{Cu}$ seed $^{-1}$ were considered. At the two-leaf stage, plants were carefully removed from sand and rinsed in deionized water. Afterwards, roots and shoots were separated and oven-dried at $60^{\circ} \mathrm{C}$ until constant mass, followed by weighing in analytical scale $(0.0001 \mathrm{~g})$. The root and shoot samples were submitted to a tissue analysis of $\mathrm{Cu}$ concentration, according to the procedures described by Malavolta et al. (1997).

Values of root and shoot dry mass and $\mathrm{Cu}$ tissue content allowed calculating the uptake and incorporation efficiencies of this element by maize, following the method described by Baligar et al. (2001). The uptake efficiency (UE) was calculated as the ratio of total $\mathrm{Cu}$ content in the plant, in $\mathrm{mg}$, and root dry weight, in g; the incorporation efficiency (IE) was based on the Cu content in shoots, in mg, divided by the total $\mathrm{Cu}$ content in the plant, in $\mathrm{mg}$.

Data was analyzed using the JMP ${ }^{\circledR}$ statistical software (SAS Institute, version 10). Results from seed vigor tests were submitted to ANOVA and, in case of significance, means were compared by Tukey test $(\mathrm{p}<0.05)$; data of tissues dry mass and $\mathrm{Cu}$ uptake was submitted to regression analysis.

\section{RESULTS AND DISCUSSION}

Results of seedling emergence (SE) are presented on table 1 , specified by each treatment and evaluation period. In the first and third periods ( 1 and 120 days), no difference was verified between dosages and $\mathrm{Cu}$ formulations, while in the second period (60 days), the treatment containing $0.44 \mathrm{mg} \mathrm{Cu} \mathrm{seed}^{-1}$ presented lower SE compared to non-treated seeds and did not differ from the other dosages.

The speed of seedling emergence (SSE) was affected by the treatments containing $\mathrm{Cu}$, with variable results among dosages, formulations and periods of testing (Table 2). The

Table 1. Maize seedling emergence evaluated with different dosages of $\mathrm{Cu}$, applied to seeds as cuprous oxide $(\mathrm{CuOxi})$ and copper oxychloride $(\mathrm{CuOxy})$. The evaluations were conducted in three periods: 1, 60 and 120 days after $\mathrm{Cu}$ application

\begin{tabular}{|c|c|c|c|c|c|c|c|}
\hline \multicolumn{2}{|c|}{$\begin{array}{l}\text { Cu dosages } \\
\left(\mathrm{mg} \mathrm{Cu} \mathrm{seed}^{-1}\right)\end{array}$} & 0 & 0.11 & 0.22 & 0.44 & 0.88 & 1.76 \\
\hline $\begin{array}{l}\text { Period } \\
\text { (days) }\end{array}$ & Treatment & \multicolumn{6}{|c|}{$\%$} \\
\hline \multirow{2}{*}{1} & CuOxi & 99Aa1 & $98 A a$ & 99Aa & $98 \mathrm{Aa}$ & 99Aa & 99Aa \\
\hline & CuOxy & 99Aa & 99Aa & 99Aa & $98 \mathrm{Aa}$ & 99Aa & $98 \mathrm{Aa}$ \\
\hline \multirow{2}{*}{60} & CuOxi & 99Aa & 99Aab & 99Aab & $95 \mathrm{Ab}$ & 97Aab & 96Aab \\
\hline & CuOxy & 99Aa & 99Aab & 97Aab & $95 \mathrm{Ab}$ & 97Aab & 97Aab \\
\hline \multirow{2}{*}{120} & CuOxi & $100 A a$ & $98 A a$ & $99 A a$ & 99Aa & $95 \mathrm{Aa}$ & 97Aa \\
\hline & CuOxy & $100 A a$ & 99Aa & 97Aa & $100 \mathrm{Aa}$ & 99Aa & $98 \mathrm{Aa}$ \\
\hline
\end{tabular}

${ }^{1}$ Means followed by the same uppercase letter in the column and lowercase letter in the row do not differ by Tukey test $(\mathrm{p}<0.05)$.

Table 2. Speed of maize seedling emergence evaluated with different dosages $\mathrm{Cu}$, applied to seeds as cuprous oxide $(\mathrm{CuOxi})$ and copper oxychloride (CuOxy). The evaluations were conducted in three periods: 1, 60 and 120 days after copper application

\begin{tabular}{|c|c|c|c|c|c|c|c|}
\hline \multicolumn{2}{|c|}{$\begin{array}{l}\text { Cu dosages } \\
\left(\mathrm{mg} \mathrm{seed}^{-1}\right)\end{array}$} & 0 & 0.11 & 0.22 & 0.44 & 0.88 & 1.76 \\
\hline $\begin{array}{l}\text { Period } \\
\text { (days) }\end{array}$ & Treatment & \multicolumn{6}{|c|}{ Index } \\
\hline \multirow{2}{*}{1} & CuOxi & 21.9Aa1 & 19.7Aa & $19.5 \mathrm{Aa}$ & 19.3Aa & $20.0 \mathrm{Aa}$ & 19.6Aa \\
\hline & CuOxy & 21.9Aa & 20.3Aab & 20.5Aab & 19.1Ab & 20.3Aab & 20.1Aab \\
\hline \multirow{2}{*}{60} & CuOxi & 21.3Aa & 20.4Aab & 20.3Aab & 19.0Ab & $18.8 \mathrm{Ab}$ & 18.7Ab \\
\hline & CuOxy & $21.3 \mathrm{Aa}$ & 20.3Aab & $19.2 \mathrm{Ab}$ & 18.7Ab & 19.7Aab & 19.9Aab \\
\hline \multirow{2}{*}{120} & CuOxi & 19.7Aa & 19.5Aab & 19.6Aab & 19.4Aab & 18.6Aab & $18.6 \mathrm{Ab}$ \\
\hline & CuOxy & 19.7Aa & 19.3Aa & $19.2 \mathrm{Aa}$ & 19.5Aa & 19.2Aa & 18.7Aa \\
\hline
\end{tabular}

${ }^{1}$ Means followed by the same uppercase letter in the column and lowercase letter in the row do not differ by Tukey test $(\mathrm{p}<0.05)$. 
control treatment (non-treated seeds) presented higher absolute values for SSE among all treatments and periods, and significant differences occurred randomly with the dosages of $0.22,0.44,0.88$ and $1.76 \mathrm{mg} \mathrm{Cu} \mathrm{seed}^{-1}$.

Data of root and shoot dry mass is presented on figure 1 . Root dry mass values did not significantly differ among the dosages of $\mathrm{Cu}$, for both formulations, although a lower mean value was obtained at the dosage of $1.76 \mathrm{mg} \mathrm{Cu}$ seed $^{-1}$ applied as cuprous oxide. For shoots, only cuprous oxide significantly increased the dry mass, however, the difference were almost non-significant at the $5 \%$ significance level $(\mathrm{p}=0.047)$.

The $\mathrm{Cu}$ tissue concentration in roots presented a linear response for both formulations, increasing as $\mathrm{Cu}$ dosages increased, while shoot concentration presented a quadratic response, with maximum values obtained at the dosages of 1.16 and $1.10 \mathrm{mg} \mathrm{Cu} \mathrm{seed}^{-1}$ for cuprous oxide and copper oxychloride, respectively (Figure 2). The $\mathrm{Cu}$ tissue concentration ranged from 61.65 to $677.33 \mathrm{mg} \mathrm{Cu} \mathrm{kg}^{-1}$ in roots and 5.87 to $25.93 \mathrm{mg} \mathrm{Cu} \mathrm{kg}^{-1}$ in shoots.

The $\mathrm{Cu}$ uptake efficiency (UE) presented a linear response for both formulations, with higher UE values as higher dosages of $\mathrm{Cu}$ were applied to seeds (Figure 3); cuprous oxide presented higher UE values at all dosages compared to copper oxychloride. For the incorporation efficiency (IE), also in figure 3, there was a quadratic response, with decreases of IE values with increasing amounts of seed-applied $\mathrm{Cu}$. Both formulations presented similar IE values, and could not be differentiated by this parameter.

To a certain extent, results of seed vigor (Table 2) indicate a negative effect of $\mathrm{Cu}$ only for SSE; SE values ranged from 95 to $100 \%$ and the treatments containing the highest dosages $\mathrm{Cu}\left(0.88\right.$ and $\left.1.76 \mathrm{mg} \mathrm{Cu} \mathrm{seed}^{-1}\right)$ did not differ from the control. By evaluating the mean values of SSE, it's possible to verify that non-treated seeds provided higher results than any treatment containing $\mathrm{Cu}$-treated seeds, although significant difference started only at the dosage of $0.22 \mathrm{mg} \mathrm{Cu}$ seed $^{-1}$.

According to Mondo et al. (2013), variation in maize SE affects subsequent plant growth, with late-emerging plants being in disadvantage compared to earlier emerging plants. Thus, a fast and uniform initial development of plants is highly desired for maize crop, especially under stressful conditions. Foti et al. (2008) found that small amounts of $\mathrm{Cu}$ applied via seed priming on maize increased the number of germinated seeds compared to the control. On the contrary, Luchese et al. (2004) reported a toxic effect

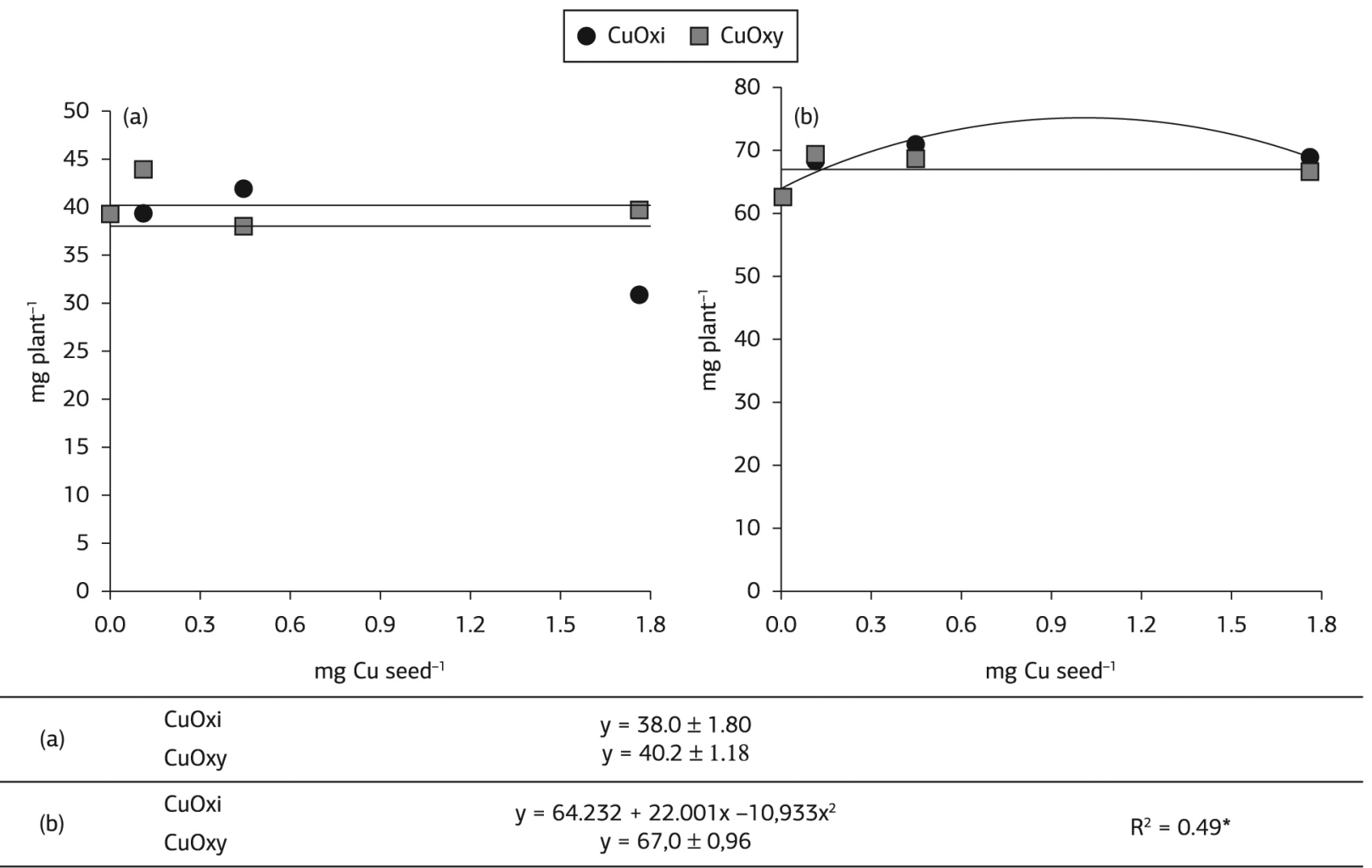

*Difference between means are significant by F-Test $(p<0.05)$. Numbers following the signal " \pm " represents the Standard Mean Error (SME).

Figure 1. Root (a) and shoot (b) dry mass of two-leaf maize plants (hybrid 2B688Hx). Treatments correspond to different dosages of seedapplied $\mathrm{Cu}$, provided via cuprous oxide $(\mathrm{CuOxi})$ and copper oxychloride $(\mathrm{CuOxy})$. 
CuOxi $\square$ CuOxy
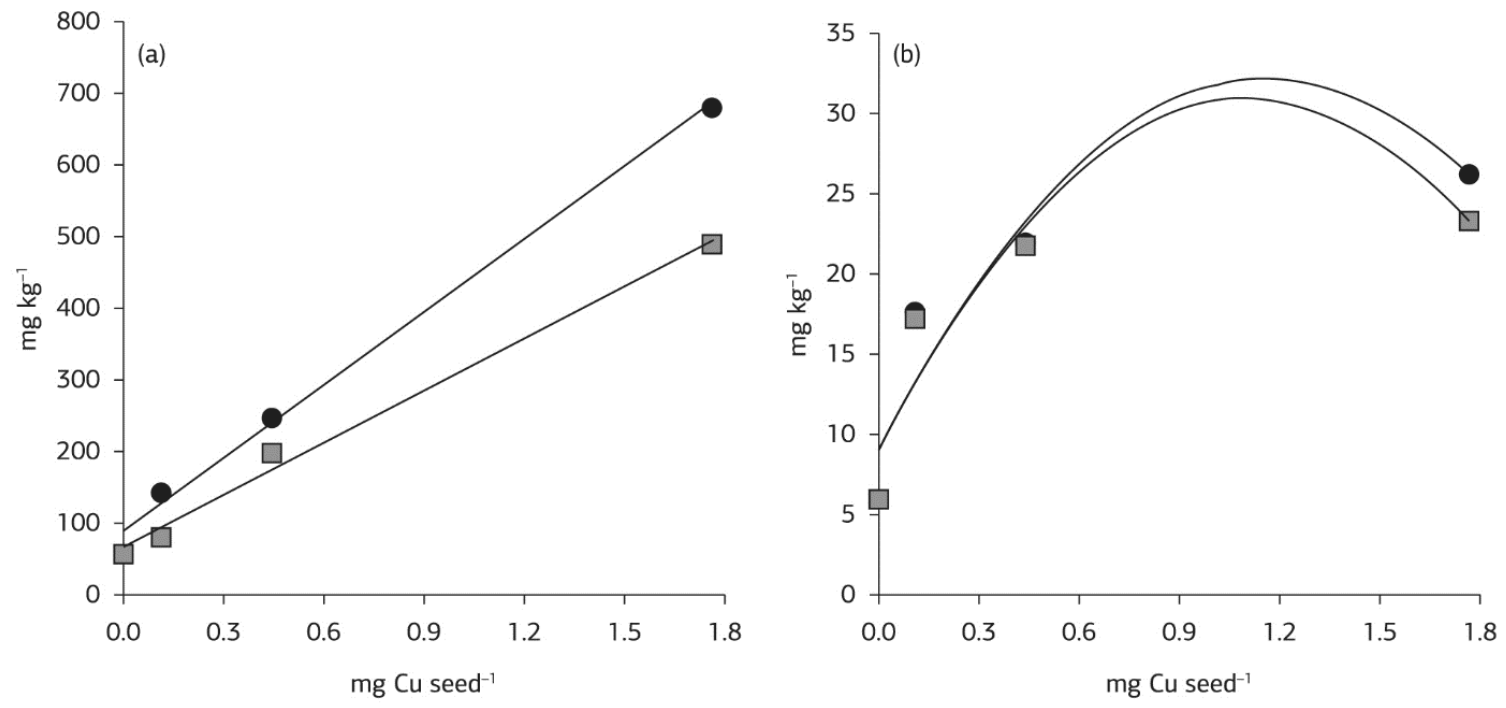

\begin{tabular}{cccc}
\hline (a) & CuOxi & $\mathrm{y}=87.059+337.71 \mathrm{x}$ & $\mathrm{R}=0.97^{*}$ \\
& CuOxy & $\mathrm{y}=68.343+242.02 \mathrm{x}$ & $\mathrm{R}^{2}=0.87^{*}$ \\
\hline \multirow{2}{*}{ (b) } & CuOxi & $\mathrm{y}=8.879+39.792 \mathrm{x}+17.125 \mathrm{x}^{2}$ & $\mathrm{R}^{2}=0.85^{*}$ \\
& CuOxy & $\mathrm{y}=8.748+39.721 \mathrm{x}+17.967 \mathrm{x}^{2}$ & $\mathrm{R}^{2}=0.84^{*}$ \\
\hline
\end{tabular}

*Difference between means are significant by F-Test $(p<0.05)$.

Figure 2. Cu tissue concentration of roots (a) and shoots (b) of two-leaf maize plants (hybrid 2B688Hx). Treatments correspond to different dosages of seed-applied $\mathrm{Cu}$, provided via cuprous oxide (CuOxi) and copper oxychloride (CuOxy).

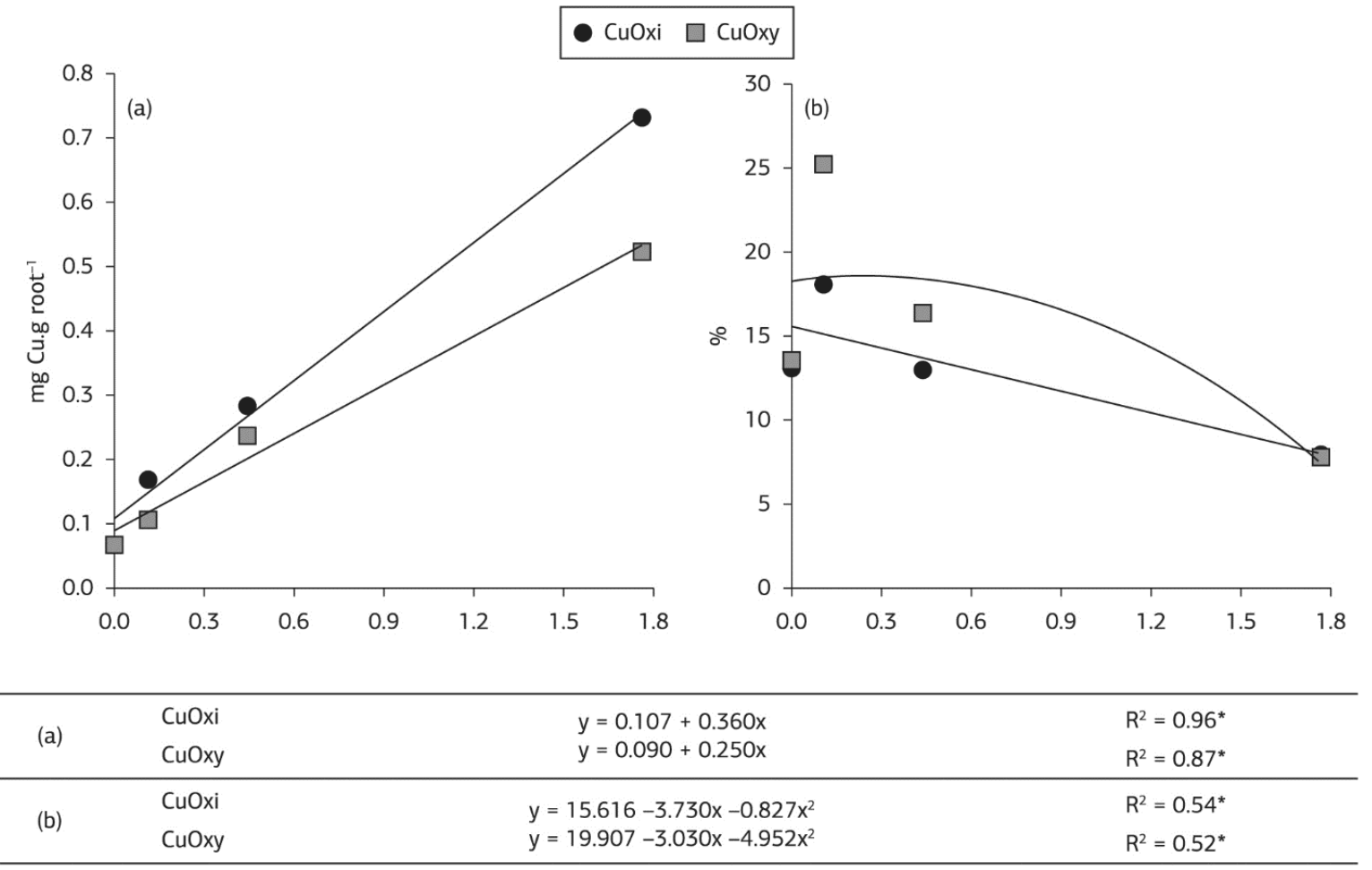

${ }^{*}$ Difference between means are significant by F-Test $(p<0.05)$.

Figure 3. Cu uptake (a) and incorporation (b) efficiencies determined at the two-leaf stage of maize (hybrid 2B688Hx). Treatments correspond to different dosages of seed-applied $\mathrm{Cu}$, provided via cuprous oxide (CuOxi) and copper oxychloride $(\mathrm{CuOxy})$. 
of $\mathrm{Cu}$ applied via maize seeds, obtaining lower seedling emergence percentages.

Despite the similar values of shoot dry mass obtained among all treatments, visual symptoms of $\mathrm{Cu}$ toxicity could be observed with the highest dosages ( 0.88 and $1.76 \mathrm{mg} \mathrm{Cu} \mathrm{seed}^{-1}$ ), such as leaf necrosis and plant stunting, which are common symptoms of $\mathrm{Cu}$ toxicity in maize (Yruela, 2005).

Under $\mathrm{Cu}$ toxicity, root growth usually is inhibited before shoot growth, as the first are a preferential site of $\mathrm{Cu}$ accumulation (Broadley et al., 2012). The mechanisms to resist excess $\mathrm{Cu}$ by plants include: binding the element to cell walls, restrict the influx through plasma membrane, stimulation of efflux from the cytoplasm, compartmentalization of $\mathrm{Cu}$ in the vacuole and chelation at the cell wall-plasma membrane interface (Yruela, 2009). In this experiment, roots accumulated considerably higher proportions of $\mathrm{Cu}$ than shoots, however, non-significant effect between roots dry mass values were verified.

The linear positive response of $\mathrm{Cu} \mathrm{UE}$ to the increasing dosages of $\mathrm{Cu}$ can be mainly explained by the root accumulation, as $\mathrm{Cu}$ shoot concentration represented a considerably lower amount of $\mathrm{Cu}$ in the entire plant. In the case of IE, which basically considers the amount of $\mathrm{Cu}$ transported to shoots, there was a reduction as higher amounts of $\mathrm{Cu}$ were applied. This is an expected response, as plants ability to remobilize $\mathrm{Cu}$ from roots to shoots is limited (Broadley et al., 2012); also, the plants ability to utilize any nutrient tends to decreases as their availability increases (Baligar et al., 2001).

Copper seed treatment may consist in a good option for maize cultivated in soils with low $\mathrm{Cu}$ availability (Karamanos \& Goh, 2004; Malhi et al., 2005; Karamanos et al., 2005; Malhi, 2009). However, soil or foliar applications may also be needed in order to totally supply the crop demand for this micronutrient. Moreover, the application of $\mathrm{Cu}$ may present advantages in terms of plant's disease management, mainly by controlling certain types of fungal pathogens (Peruch \& Bruna, 2008)

This research demonstrates that both cuprous oxide and copper oxychloride can be used as maize seed treatment. The formulations did not negatively affect the final seedling emergence and the tissues dry mass, while provided a significant uptake of $\mathrm{Cu}$ by plants. However, a delayed seedling emergence is expected.

\section{CONCLUSION}

Seed-applied $\mathrm{Cu}$ reduces the speed of maize seedling emergence, while the final emergence percentage is not affected. Shoot dry mass tends to increase with the application of $\mathrm{Cu}$, while there is no interference on root dry mass within the dosages tested. $\mathrm{Cu}$ tissue concentration of both roots and shoots increases as higher dosages of $\mathrm{Cu}$ are applied to seeds, with higher accumulation in roots. Cuprous oxide promotes higher uptake of $\mathrm{Cu}$ by maize roots compared to copper oxychloride.

\section{ACKNOWLEDGEMENTS}

The authors express their appreciation to FAPESP (São Paulo State Research Foundation) for financial support (FAPESP Application number: 2012/05598-9) and Agrichem do Brasil S.A. for providing the copper formulations.

\section{REFERENCES}

Baligar, V. C., Fageria, N. K., \& He, Z. L. (2001). Nutrient use efficiency in plants. Communications in Soil Science and Plant Analysis, 32, 921-950. http://dx.doi.org/10.1081/CSS-100104098.

Brasil. Ministério da Agricultura, Pecuária e Abastecimento (2009). Regras para análise de sementes. Brasília, DF: MAPA/ACS. 399 p.

Broadley, M., Brown, P., Cakmak, I., Rengel, Z., \& Zhao, F. (2012). Function of nutrients: micronutrients. In P. Maschner (Ed.), Marchner's mineral nutrition of higher plants (3 ed., p. 191-248). London: Elsevier.

Cakmak, I. (2000). Role of zinc in protecting plant cells from reactive oxygen species. The New Phytologist, 146, 185-205. http://dx.doi. org/10.1046/j.1469-8137.2000.00630.x.

Dias, M. A. N., Mondo, V. H. V., \& Cicero, S. M. (2010). Vigor de sementes de milho associado à matocompetição. Revista Brasileira de Sementes, 32, 93-101. http://dx.doi.org/10.1590/S010131222010000200011 .

Epstein, E., \& Bloom, A. J. (2004). Mineral nutrition of plants: principles and perspectives (5 ed.). Sunderland: Sinauer Associates. $400 \mathrm{p}$.

Fageria, N. K., \& Stone, L. F. (2004). Produtividade de feijão no sistema plantio direto com aplicação de calcário e zinco. Pesquisa Agropecuaria Brasileira, 39, 73-78. http://dx.doi.org/10.1590/S0100204X2004000100011.

Farooq, M., Wahid, A., Kadambot, H., \& Siddique, M. (2012). Micronutrients application through seed treatments - a review. Journal of Soil Science and Plant Nutrition, 12, 125-142. http:// dx.doi.org/10.4067/S0718-95162012000100011.

Foti, R., Abureni, K., Tigere, A., Gotosa, J., \& Gere, J. (2008). The efficacy of different seed priming osmotic on the establishment of maize (Zea mays L.) caryopses. Journal of Arid Environment, 72, 1127-1130. http://dx.doi.org/10.1016/j.jaridenv.2007.11.008.

Karamanos, R. E., \& Goh, T. B. (2004). Effect of rate of copper application on the yield of hard red spring wheat. Communications in Soil Science, 35, 2037-2047. http://dx.doi.org/10.1081/CSS200026834.

Karamanos, R. E., Walley, F. L., \& Flaten, P. L. (2005). Effectiveness of seedrow placement of granular copper products for wheat. Canadian 
Journal of Soil Science, 85, 295-306. http://dx.doi.org/10.4141/ S04-038.

Luchese, A. V., Gonçalves, A. C., Luchese, E. B., \& Braccini, M. C. L. (2004). Emergência e absorção de cobre por plantas de milho em resposta ao tratamento de sementes com cobre. Ciência Rural, 34, 1949-1952. http://dx.doi.org/10.1590/S0103-84782004000600044.

Maguire, J. D. (1962). Speed of germination aid in selection and evaluation for seedling emergence and vigor. Crop Science, 2, 176-177. http://dx.doi.org/10.2135/cropsci1962.0011183X000200020033x.

Malavolta, E. (2006). Manual de nutrição mineral de plantas. São Paulo: Agronômica Ceres. 638 p.

Malavolta, E., Vitti, G. C., \& Oliveira, S. A. (1997). Avaliação do estado nutricional das plantas, princípios e aplicaçóes (2 ed.). Piracicaba: Potafos. 319 p.

Malhi, S. S. (2009). Effectiveness of seed-soaked Cu, autumn- versus spring-applied $\mathrm{Cu}$, and $\mathrm{Cu}$-treated $\mathrm{P}$ fertilizer on seed yield of wheat and residual nitrate- $\mathrm{N}$ for a $\mathrm{Cu}$-deficient soil. Canadian Journal of Plant Science, 89, 1017-1030. http://dx.doi.org/10.4141/CJPS08189.

Malhi, S. S., \& Leach, D. (2012). Reducing toxic effect of seed-soaked $\mathrm{Cu}$ fertilizer on germination of wheat. Agricultural Sciences, 3, 674677. http://dx.doi.org/10.4236/as.2012.35082.

Malhi, S. S., Cowell, L., \& Kutcher, H. R. (2005). Relative effectiveness of various sources, methods, times and rates of copper fertilizers in improving grain yield of wheat on a $\mathrm{Cu}$ deficient soil. Canadian Journal of Plant Science, 85, 59-65. http://dx.doi.org/10.4141/P04-089.

Mondo, V. H. V., Cicero, S. M., Dourado, D., No., Pupim, T., \& Dias, M. A. N. (2013). Effect of seed vigor and intra-specific competition and grain yield in maize. Agronomy Journal, 105, 222-228. http:// dx.doi.org/10.2134/agronj2012.0261.

Nazir, M. S., Jabbar, A., Mahmood, K., Ghaffar, A., \& Nawaz, S. (2000). Morpho-chemical traits of wheat as influenced by re-sowing seed steeping in solution of different micronutrients. International Journal of Agricultural Biology, 2, 6-9.

Peruch, L. A. M., \& Bruna, E. D. (2008). Relação entre doses de calda bordalesa e de fosfito de potássio na intensidade do míldio e na produtividade da videira cv. 'Goethe'. Ciência Rural, 38, 2413-2418. http://dx.doi.org/10.1590/S0103-84782008000900001.

Scott, J. M. (1998). Delivering fertilizers through seed coatings. In Z. Rengel (Ed.), Nutrient use in crop production (p. 197-220). New York: Haworth Press Inc.

Scott, J. M., \& Blair, G. J. (1988). Phosphorus seed coatings for pasture species. I. Effect of source and rate of phosphorus on emergence and early growth of phalaris (Phalaris aquatic L.) and Lucerne (Medicago sativa L.). Australian Journal of Agricultural Research, 39, 437-445. http://dx.doi.org/10.1071/AR9880437.

Taylor, A. G., Allen, P. S., Bennett, M. A., Bradford, K. J., Burris, J. S., \& Misra, M. K. (1998). Seed enhancements. Seed Science Research, 8, 245-256. http://dx.doi.org/10.1017/S0960258500004141.

Yruela, I. (2005). Copper in plants. Brazilian Journal of Plant Physiology, 17, 145-156. http://dx.doi.org/10.1590/S1677-04202005000100012.

Yruela, I. (2009). Copper in plants: acquisition, transport and interactions. Functional Plant Biology, 36, 409-430. http://dx.doi. org/10.1071/FP08288. 